\title{
Oppimisen aikakauden täyttymättömät haaveet
}

\author{
Michael Welton
}

Markkinat - kuten isät ennen vanhaan - tietävät parhaiten. Vai tietävätkö?

Mutta mitä ovatkaan työn vaikutukset työntekijöihin uuskapitalismissa? Missä määrin me aikuiskasvatuksen tutkimusyhteisön jäsenet yritämme oppia ymmärtämään sitä, miten tavalliset ihmiset kykenevät näkemään elämänsä mielekkäänä jatkuvana tarinana samalla, kun he joutuvat työpaikkojen supistusten, yritysten sisäisten uudelleenjärjestelyjen ja toimintojen ulkoistamisen kohteiksi? Meidän on liian helppoa unohtaa ne ihmiset, jotka Kagarlitskya lainaten - eivät asu "teknologisen vallankumouksen pilvenpiirtäjän" ylimmissä kerroksissa.

Hampurissa vuoden 1997 heinäkuussa pidetyn UNESCO:n viidennen kansainvälisen aikuiskasvatuskonferenssin päätöspuheessaan Federico Mayor julisti painokkaasti konferenssin merkinneen käännekohtaa: ensimmäistä kertaa aikuiskasvatuskeskustelun historiassa tuottavuus ja demokratia nähtiin ihmisen kehityksen samanaikaisina edellytyksinä. Konferenssissa oli "otettu uudelleen esiin yhteisöllisen osallistumisen keskeinen merkitys." Konferenssi tiedosti sen, mikä merkitys paikallisten ihmisten tiedoilla, oppimisjärjestelmillä ja organisaatiomalleilla voi olla koulutusaloitteiden menestykseen ja pysyvyyteen. Mayorille Hampurin konferenssi merkitsi siirtymistä passiivisesta aktiiviseen ja ihmiskeskeiseen lähestymistapaan koulutuksessa, terveydenhuollossa, maataloudessa ja kaikilla muillakin yhteiskunnallisen ja taloudellisen kehityksen alueilla (Mayor 1997, ss. 2-3). Mayor us- koi, että nyt oli oikea aika tarttua tilaisuuteen, löytää toiminnan perusteet uudelleen ja ryhtyä töihin. Sen sijaan, että rakentaisimme seinän tuulensuojaksi, meidän tulee - Mayoria lainaten rakentaa tuulimylly ja valjastaa sitä valtavaa inhimillistä energiaa, jota aikuiskasvatus ja elinikäinen oppiminen voivat saada aikaan (emt.). Ei kuitenkaan ole helppoa rakentaa tuulimyllyä, kun ulkona raivoaa pyörremyrsky.

Federico Mayorin voimakkaasti painottama "ihmiskeskeinen toimintamalli” löytää kaikupohjaa myös suomalaisesta aikuiskasvatustutkimuksesta ja toimintatapatraditioista. Suomen ensimmäinen aikuiskasvatuksen professori Urpo Harva vaati, että suomalaisessa yhteiskunnassa tulisi vaalia länsimaista, humanistista kasvatusnäkemys$t a ̈$, jonka juuret ovat antiikin Kreikassa. Hän luotti siihen, että kehittyvä humanistinen näkökulma [the de- 
velopmental humanist perspective $]^{1}$ kasvavasta ja kehittyvästä yksilöstä ja yhteiskunnasta voisi innostaa aikuiskasvattajia heidän tutkimus- ja käytännön työssään. Pedagoginen uuden keksiminen ja tutkijain pohdinnot voisivat auttaa aikuiskasvattajia työssä 'hyvän yhteiskunnan' toteuttamiseksi. Mayorin tavoin myös Harva uskoi, että tuottavuus ja demokratia ovat inhimillisen kehityksen rinnakkaisia edellytyksiä. Uransa myöhempinä aikoina Harva kuitenkin vaistosi, että tuottavuuden institutionaaliset ylläpitäjät saattoivat toimia myös inhimillisen kehityksen esteinä. "Onko nyt luotava uudenlainen käsitys työn merkityksestä ja arvosta ottamalla ajatusvirikkeitä kreikkalaisesta humanismista", hän pohti (1981). Vaikutti siltä, kuin Harva olisi kysynyt, voitaisiinko työ järjestää sellaiseksi, että se edistäisi ihmisen koko kapasiteetin puhkeamista kukkaansa.

$A_{\text {nen aikuiskasvatuksen professori, muistut- }}^{\text {ulis Alanen, toinen tunnustettu suomalai- }}$ ti meitä kymmenisen vuotta sitten siitä, että 1920-luvulla suomalaista vapaata aikuiskasvatusta innoitti omistautuminen "persoonallisuuden kokonaisvaltaiselle kehittämiselle humanismin hengessä” $(1988,2)$. Alasen mielestä tämä $h u$ manistinen arvofilosofia oli myös säilytetty aikuiskoulutuskomitean loppuraportissa vuodelta 1975. Tässä raportissa tunnustettiin persoonallisuuden kasvun merkitys ja nähtiin välttämättömänä toteuttaa inhimilliset perusarvot tuotannon kehittämisessä. Vuoden 1975 raportissa ei haluttu nähdä ihmiskuntaa objektina vaan prosessina, ja siinä puhuttiin inhimillisestä potentiaalista kehittää kaikkia kykyjämme. Valitettavasti nämä kauniit unelmat ihmiskeskeisestä, arvolähtökohtaisesta toiminnasta joutuivat vastakkain sen karumman todellisuuden kanssa, jonka aiheutti 1970-luvun lopulla ja 1980-luvulla voimistunut tendenssi teknokraattisiin lähestymistapoihin sekä julkishallinnossa että markkinataloudessa. Alanen jopa ajatteli, että 'markkinalähtöinen ajattelutapa' oli ujuttautunut perinteisten suomalaisten kansanopistojen käytäntöihin. Yhä kasvavassa määrin ihmiset nyt kuluttivat aikuiskasvatuskokemuksia saavuttaakseen itselleen sosiaalista arvostusta ja kulttuurista pääomaa.
$\mathrm{J}^{\mathrm{s}}$ kka Tuomiston viimevuosien kirjoitukset ovat äsitelleet elämänikäisen oppimisen vaatimuksia ja mahdollisuuksia markkinasuuntautuneessa yhteiskunnassa (1998, ks. myös 1999), ja ne tarjoavatkin vankan sillan kommenteilleni, joita tässä kirjoituksessa haluan esittää. On kiintoisaa huomata, että Tuomisto aloittaa kirjoituksensa Elinikäinen oppiminen Suomessa: julkinen politiikka ja todellisuus esittämällä, että ihmisen kehitys persoonana ja kulttuurisena olentona tapahtuu aina jossakin historiallisessa ja sosiaalisessa kontekstissa (Tuomisto 1998, 155). Huomattavimmat alueet, missä tämä ilmenee, ovat toimiminen kansalaisena sekä työntekijän tai palkkatyöläisen rooli. Tuomiston mielestä nykyinen elinikäistä oppimista koskeva keskustelu on humanistisen tradition kannalta huolestuttavaa. Oppimisen aikakauden kauniina kimaltelevan pinnan alta paljastuva karu todellisuus ilmenee kuitenkin eräänlaisena kehittyvälle humanistiselle ajattelulle käänteisenä puolena. Tuomiston mukaan eivät edes oppivien organisaatioiden oppimisstrategiat useinkaan ota kylliksi huomioon yksittäisten työntekijöiden kehitystarpeita (emt., 161).

Kuten Alanen ja Harva, myös Tuomisto havaitsee meneillään olevan siirtymän vanhoista suomalaisista aikuiskasvatusperinteistä kohti markkinamallia. Kysymys, jonka eteen Tuomisto meidät asettaa ja jonka myös itse haluan nostaa esiin, on se, kykeneekö markkinamalli "edistämään ja parantamaan yksilölle, kansalaiselle ja palkansaajalle asetettuja vaatimuksia" (emp., 165) näinä muutoksen ja epävarmuuden aikoina. Aivan erityisesti haluan tarkastella niitä haasteita, joita informaatio- ja oppimisyhteiskunta asettaa kehittyvälle humanisen ajattelun traditiolle.

Näkemykseni mukaan kehittyvän humanismin eräs perusoletus on se, ettei yksilön oppimispotentiaalia voi irroittaa siitä institutionaalisesta kontekstista, jossa hän toimii. Instituutioihin liittyvät toimintatavat ja sosiaalisten roolien joukot muokkaavat yksilöä ja muovaavat hänen luonnettaan tukemalla tai rajoittamalla eri tavoin hänelle mahdollisten toimintatapojen valikoimaa sekä hänen tapojaan olla vuorovaikutuksessa toisten kanssa. Aikuiskasvatuksen tutkimus- ja toi- 


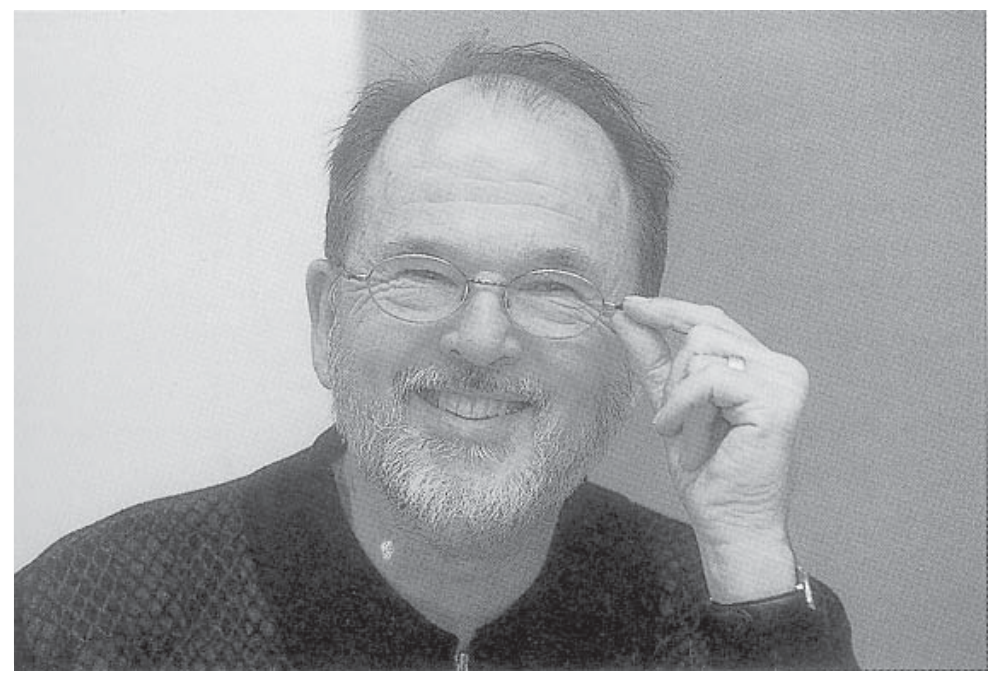

"Edessämme on eräänlaisen kyberapartheidin uhka, jossa siltoja rakentavien sosiaalisen pääoman muotojen osuus vähenee samalla, kun eliittiverkostot muuttuvat vähäosaisten kannalta yhä vaikeapääsyisemmiksi. Internet ei myöskään ole mobilisoinut aiemmin passiivisia ihmisryhmiä”, referoi Michael Welton Robert Putnamia. Putnamin tutkimuksista lisää Weltonilta s. 18-20.

mintaperinteet sekä Pohjois-Amerikassa että Pohjoismaissa ovat julistaneet, että ihmisillä on kykyä itsensä kehittämiseen ja kriittiseen ajatteluun.

Yksi kehityshumanistiselle näkökulmalle omistautuneitten keskeisistä haasteista on oppia ymmärtämään, millä tavoin meidän jäsennelty, yhteen kytkeytynyt, verkostoitunut ja tieto-orientoitunut yhteiskuntamme edesauttaa ihmisen kehitykseen ja vapautumiseen tähtäävää oppimista. Tai toisinpäin: miten se epää meiltä mahdollisuuden kehittyä tietävämmiksi ja osaavammiksi toimijoiksi elämän perustavimmilla alueilla (Welton 1995, s.133-135).

\section{Kaikki kiinteä ja pysyvä haihtuu}

$\mathrm{I}^{\mathrm{n}}$ nformaatioyhteiskunnan kauniiden unelmien näkijät lupaavat meille monia suuria ja ihmeellisiä asioita. Teknoutopistit väittävät, että 'tietotekniikan vallankumous’ takaa ikuisesti dynaamisen talouden, joka tuottaa käsittämätöntä vaurautta monille ja tekee jotakuinkin kaikkien ihmisten elämän paremmaksi. Informaatioyhteiskunnan ideologien käsissä markkinat on jopa muutettu demokratian erotuomarin rooliin eräänlaisena markkinapopulismina, mikä tekee poliittisen harkinnan tarpeettomaksi. Markkinat tarjoavat ihmisille sitä, mitä he haluavat, ja Bill Gatesista tulee jokamiehen etujen puolustaja. Markkinat - kuten isät ennen vanhaan - tietävät parhaiten.
Informaatioyhteiskunnan ideologit lupaavat ihmiselle myös "valtavasti helpottuneen pääsyn käsiksi hänen hyvinvointinsa kannalta välttämättömään informaatioon” (Rule 2000, s. 83). Verkkosivuilta tavalliset kansalaiset voivat saada asiantuntijoilta terveydentilaansa koskevia neuvoja. He voivat hoitaa pankkiasiansa tarvitsematta jonottaa kassalle. He voivat ostaa verkon kautta tavaroita yhtiöiltä, joiden ei tarvitse käyttää resurssejaan mainontaan. Valinnan mahdollisuudet näyttävät laajenevan loputtomiin, kun informaatioteknologiaa tarjotaan meille suurena sosiaalisen tasa-arvon tuojana.

Tämän sinänsä varsin harmittoman teknoutopian taustalla kaikuu kuitenkin myös karumpi viesti. On valtavat paineet siihen, että jokaisen ihmisten välisen vuorovaikutuksen ja oppimisen alueen tulisi nousta tiedon valtaväylää kiitävään junaan. Meille kerrotaan yksiselitteisesti, että raiteita on vain yhdet ja että ne johtavat kyberavaruuteen. Kaikki muut reitit johtavat umpikujiin. Oppilaitten vanhemmat ja julkinen hallinto painostavat yhdessä opettajia hankkimaan kouluihin tietokoneita. Kukaan ei kuitenkaan tunnu tarkkaan tietävän, mitä niillä sitten pitäisi tehdä. Kansalaisille kerrotaan, että tietokoneiden välityksellä pidettävät kyläkokoukset voivat korvata vanhanaikaiset kasvokkain tapahtuvat tapaamiset, joita menneitten aikojen aikuiskasvattajilla oli tapana järjestää. Kertojia ei tunnu haittaavan, että tuskin kukaan on koskaan osallistu- 
nut moiseen tietokonevälitteiseen kokoontumiseen. Kuluttajia rohkaistaan jäämään kotiin, välttämään keskustan ruuhkaisia kauppoja ja tekemään ostoksensa internetin kautta. Ja OECD:n eliitti lupaa meille, että oppiva yhteiskunta [learning society] edistää henkilökohtaista kasvua, vahvistaa demokraattisia arvoja, kehittää yhteisöjen elämää, ylläpitää sosiaalista yhteenkuuluvuutta ja lisää innovaatiota, tuottavuutta ja taloudellista kasvua. Kaiken tämän auringonpaisteen keskellä olevat varjot erottuvat kuitenkin räikeän selvinä.

Ei esimerkiksi tarvita paljoakaan mielikuvitusta erottamaan OECD:n puheissa vallitsevan ristiriitaisuuden, kun se toisaalta varoittaa työpaikkojen uhanalaisuudesta ja toisaalta julistaa vaalivansa ihmisten henkilökohtaista kehittymistä. Amerikkalainen sosiologi Richard Sennett on kirjassaan The Corrosion of Character (1998) dokumentoinut, miten epävarmat ja joustavat työpaikat sekoittavat ja hämmentävät niitä ihmisiä, jotka on pakotettu uusiin työskentelytapoihin. Mitkä ovatkaan työn vaikutukset työntekijöihin uuskapitalismissa? Missä määrin me aikuiskasvatuksen tutkimusyhteisön jäsenet yritämme oppia ymmärtämään sitä, miten tavalliset miehet ja naiset kykenevät näkemään elämänsä mielekkäänä "jatkuvana tarinana" (s. 31) samalla, kun he joutuvat työpaikkojen supistusten, yritysten sisäisten uudelleenjärjestelyjen ja toimintojen ulkoistamisen kohteiksi? Samalla kun kiirehdimme pysyttämään oppivan talouden loistavia analyysejamme työorganisaatioiden kehityksen rinnalla, meidän on liian helppoa unohtaa ne ihmiset, jotka eivät asu "teknologisen vallankumouksen pilvenpiirtäjän” ylimmissä kerroksissa (Kagarlitsky 2000, s. 5); ihmiset, jotka eivät juurikaan halua muuttaa omaa rooliaan maailmassa, jotka eivät piittaa paljoakaan sähköisestä kaupasta ja jotka ovat liian kömpelöitä tai hitaita yhä ketterämmäksi käyvässä taloudessa; ihmiset, jotka kokoavat tietokoneita Mexico Cityn tai Moskovan reunamien rähjäisissä peltihalleissa tai työskentelevät mobiilin informaatioajan masentavissa puhelinpalvelukeskuksissa. tutkielmassaan The Condition of the English

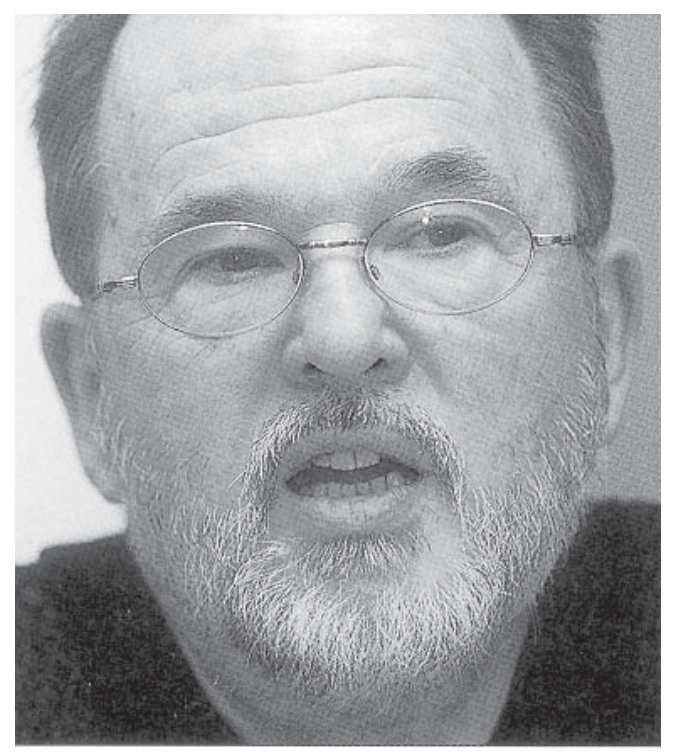

"Monet Euroopan ja Pohjois-Amerikan ajattelijat ovat syvästi huolissaan kansalaisosallistumisen ja poliittisen osallistumisen tilasta maassaan", Michael Welton muistutti.

Working Class (1844) maalaisväestöstä, joka eli päivittäistä elämäänsä täysin tietämättömänä hyökyaallosta, joka oli nousemassa juuri horisontin takana ja joka pian pyyhkäisisi heidät uuteen maailmaan täynnä kaupunkeja, tehtaita, koneita ja slummeja. 1800-luvun alkuun mennessä teollisen oppivan yhteiskunnan kaksi pääpiirrettä olivat jo tulossa näkyviin: tehtaanpiiput ja julkiset koulut rinnatusten. Massiiviset, yksittäisten ihmisten vaikutusmahdollisuuksien ulottumattomissa olevat taloudelliset ja yhteiskunnalliset voimat pakottivat ihmiset oppimaan uusia tapoja nähdä maailmansa mielekkäänä; uusia tapoja työskennellä, kun käden taitoihin liittyvän tiedon merkitys riistettiin heiltä; uusia tapoja liittoutua toisten kanssa hallitakseen elämäntilannettaan edes jotenkin; uusia tapoja vaikuttaa päätöksiä tekevään eliittiin; uusia tapoja järjestää jokapäiväinen elämänsä. Kun päivästä toiseen samanlaisena toistuvan, perinteisen, viljelyyn perustuvan maaseutuelämän kierto oli katkaistu, joutui ihmiskunta joka puolella maapalloa tunteettomasti paiskatuksi keskelle kovaa oppivaa yhteiskuntaa. Inhimillisestä potentiaalistaan vieraannutettuina ihmiset eivät enää useinkaan kokeneet maailmaa omana luomuksenaan. Kovinkaan monet työläisistä eivät viettäneet aikaansa 
istuskellen kahviloissa ja ylistäen Jumalaa kaikista niistä uusista oppimismahdollisuuksista, joita heillä nyt oli.

Teollinen vallankumous antoi myös lähtölaukauksen oppimisen aikakaudelle. Kun perinteisiltä ajattelu- ja toimintamalleilta oli ensin kadonnut pohja, ihmiset tulivat akuutisti tietoisiksi siitä, että heidän esivanhemmiltaan perimänsä elämänmallit, tavat ja rutiinit olivat menettäneet käyttökelpoisuutensa. He eivät enää voineet itsestäänselvyytenä olettaa, että heidän esivanhemmiltaan perimänsä tiedot ja taidot auttaisivat heitä löytämään suuntansa jatkuvasti muuttuvassa nykyhetkessä. Heidän oli tiedostettava itsensä henkilöinä, jotka joutuivat jatkuvasti sopeutumaan uusiin oppimishaasteisiin kaikilla teollisen yhteiskunnan olennaisilla oppimisalueilla - kansalaisyhteiskunnassa, valtiollisessa elämässä ja yksityisellä alueella. Karl Marx kiteytti tämän uuden, 1800-luvun puolivälin tienoon Euroopassa syntyneen oppimisdynamiikan sattuvaan aforismiinsa: "Kaikki kiinteä ja pysyvä sulaa ilmaan." Tämän uuden teollisuuden ajan oppimisdynamiikan yllykkeenä toimi levoton ja nopealiikkeinen teknologinen dynamiikka, joka ei juurikaan antanut tehtaanomistajille aikaa rentoutua ja hienosäätää tuotantokoneistoaan. Teollisen oppivan yhteiskunnan varhaisvaiheet olivat kuitenkin verrattain hidasliikkeisiä. Tänä päivänä mekin, niinkuin pahaa-aavistamattomat maalaiset ennen meitä, olemme tulleet imaistuksi "vauhdin maailmaan" (Plumb 1999). Itse asiassa monet maapallon asukkaista ovat meidän aikamme uusia 'teknomaalaisia', jotka eivät kenties ole vielä käyttäneet edes puhelinta, kun taas me täällä rikkaassa pohjolassa päivitämme tietokoneitamme jo sadannen kerran.

$\mathrm{M}^{2}$ aailmanhistoriassa ollaan astumassa maailmanlaajuisen verkottumisen aikaan. Viimeisen kolmen vuosikymmenen aikaisen muutoksen suunta pakottaa meidät arvioimaan uudelleen aikaan, tilaan ja alueelliseen organisaatioon liittyviä kysymyksiä ja asettamaan ne "kysymyksenasettelun viitekehyksen keskipisteeseen" tämän uuden aikakauden merkityksen suhteen (Albrow, 2000, s. 118). Globaalisti verkottunut maailma tuo meille uusia oppimisen haasteita sellaisilla alueilla, kuten hallinto, kansalaisuus ja kansalaisyhteiskunnan elinvoimaisuus; työn sisältö jälkifordilaisessa ajassa; viralliset koulutusjärjestelmät; yhteiskunnallinen solidaarisuus sekä henkilökohtaiset ja sosiaaliset merkitysjärjestelmät. Suuntaan tässä oman kehityshumanistisen katseeni ‘tuotannon' ja 'kansalaisuuden' kiistanalaisiin oppimisalueisiin. Harvan, Alasen ja muiden tunnustettujen suomalaisten tutkijoiden kaltaisille humanisteille nämä kaksi elämänaluetta ovat 'hyvän yhteiskunnan' tunnusmerkkejä.

\section{Ihmisarvoinen työ}

$\mathrm{M}$ ikään ei tunnu kiihottavan informaatioyhteiskunnan ideologeja enempää, kuin saada julistaa oppivan talouden tuloa. Kenties on myös niin, ettei mikään aiheuta tämän päivän filosofien, historioitsijoiden, feministien, työn tutkijoiden ja jälkiteollisen ajan utopioiden kehittelijöiden riveissä yhtä voimakasta kahtiajakoa kuin kysymys siitä, kuinka meidän tulisi arvioida kaikkialla maailmassa meneillään olevaa työn uudelleenjärjestelyä, työn nykyistä merkitystä ja sen kehityspotentiaalia. Missä määrin nämä muutokset lunastavat lupauksia uudenlaisesta työpaikasta, jossa työntekijöillä on mahdollisuus omiin aloitteisiin, päätöksentekoon ja luovaan ajatteluun? Onko meillä hyviä syitä uskoa syntymässä olevan oppivan organisaation profeettoja?

Työn kapitalistisen organisaation ja rakenteen historiallinen ymmärtäminen johtaa syvään skeptisyyteen suhteessa niiden työpaikkojen kehityspotentiaaliin, joissa suurin osa palkkatyöläisistä joutuu näinä epävarmuuden aikoina uurastamaan. Vaikutusvaltaisessa teoksessaan Labour and Monopoly Capital: the degradation of work in the 20th century (1974) Harry Braverman esittää, että 1900-luvun kapitalistinen työn rakenne on häivyttänyt sen yhteyden, joka esiteollisen ajan käsityötaidoissa vallitsi ajattelun ja toiminnan, suunnittelun ja toteutuksen sekä käden ja mielen välillä. Vähä vähältä, taistelu taistelulta tuotantoprosessi pakotti itsestään riippuvaiset palkkatyöläiset luopumaan ammatillisesta ja sosiaalisesta kompetenssistaan ja mahdollisuu- 
destaan muokata omaa työtään. Jos Braverman on oikeassa, niin kapitalistisen tuotanto-organisaation kantava logiikka on ristiriidassa sen kanssa, että ihmisten enemmistö voisi saada kehittymismahdollisuuksia tarjoavaa, oppijakeskeistä ja osallistuvaan demokratiaan perustuvaa työtä. Onko siis mahdollista, että kapitalismin viimeisin muuntautuminen tietoon perustuvaksi, kyberneettiseksi tuotantomoodiksi kaivaakin maan teollisen oppimisyhteiskunnan logiikan alta?

$\mathrm{E}$ räät ajattelijat, kuten Shoshana Zuboff teoksessaan In the Age of the Smart Machine (1988), ovat esittäneet, että informaatioteknologian - tietokoneen välittämän työn - uusi aika tuo mukanaan radikaaleja muutoksia muuttamalla työn ominaisluonnetta siitä, miten miljoonat ihmiset kokevat päivittäisen elämänsä työpaikoillaan (Zuboff 1988, s. 11). Hän väittää, että uusien teknologioiden informaatiokapasiteetti (jotka teknologiat eivät ainoastaan automatisoi tuotantoa, vaan saattavat myös koko tuotantoprosessin näkyväksi) on olennaisesti heikentänyt kehon historiallista roolia sekä teollisessa että valkokaulustyössä, ja se kuvastaa myös esiin nousevaa henkisten taitojen kysyntää, joka usein syrjäyttää ihmiskehon ensisijaisena osaamisen lähteenä (1988, s. 16). Zuboff väittää, että uusissa tietokonevälitteisissä työmuodoissa on ainoastaan latenttina olemassa mahdollisuus ylittää taylorismi (siis murtaa hierarkkiset työmuodot ja ylhäältäpäin johdetut auktoriteettijärjestelmät ja vahvistaa työntekijöiden omia demokraattisia ja kognitiivisia voimavaroja).

Zuboffin argumentaation tyyli viehättää minua suuresti. Erityisesti minua viehättää se ovela tapa, jolla hän saa kapitalismin teknologiat yht'äkkiä taianomaisesti luomaan ainakin joillekin tietotyöläisille olosuhteet, jotka mahdollistavat kehittävän työn. (Kuitenkin samat teknologiat ovat pitkään sysänneet armottomasti ihmistyötä syrjään ja yksinkertaistaneet ihmisen oppimisympäristöä sietämättömällä tavalla).

$\mathrm{M}$ utta jokaista Zuboffia kohti on myös lukuisia huolestuneita skeptikoita. Rohkeassa kirjassaan Prometheus Wired (2000) kanadalainen taloushistorioitsija Darin Barney särkee sen
Työtehtävien ja työn sisältö-

jen suunnittelussa kehityshu-

manismi kohtaa suurimman

haasteensa: välineellisyyden

ja tehokkuuden logiikka piit-

taa hyvin vähän ihmisyksilön

kasvusta ja kukoistuksesta.

kauniin unelman, että verkkoteknologian esiinmarssi olisi saattanut liikkeelle perinpohjaisen taloudellisen muutoksen (2000, s. 105). Barney kysyy, mitä me voimme päätellä uusien teknologioiden vaikutuksesta työhön. Vaikuttaisi siltä, että kaiken kaikkiaan työntekijöiden siirtymisessä teknologian tuhoamilta aloilta teknologian mahdollistamille aloille vallitsee johdonmukainen viive. Barneyn mielestä meidän on ymmärrettävä se tapa, jolla olemassaolevia työpaikkoja katoaa näin hälyttävää vauhtia, kun niitä katoaa verkostoihin "ei ainoastaan tehtaissa, vaan myös missä tahansa työssä, jossa tarvittavat päätökset ja taidot voidaan redusoida standardisoituun ja helposti kontrolloitavaan bittimuotoon" (s. 136). Kapitalistisen työn organisaation logiikka, jonka Braverman niin koruttomasti on esittänyt, ei vielä ole liuennut informaatiotalouden lämpöiseen kylpyyn. Työ, työpaikat ja jopa kokonaiset ammattialat ovat joutumassa verkostojen poispyyhkimiksi, sillä tämä teknologia mahdollistaa tuotannon uudelleenorganisoinnin siten, että ihmistyön ja ihmisten suorittaman prosessinhallinnan määrää voidaan voimakkaasti vähentää (s. 137). Kuten Jürgen Habermas pohdiskelee Peter Dews'in haastattelemana teoksessa Autonomy and Solidarity (1992), ehkäpä ihmistyö on ollut "vastatusten oman loppunsa kanssa jo siitä asti, kun teollisessa tuotannossa ensi kertaa alettiin hajottamaan työprosesseja pienemmiksi osasiksi” (Dews 1992, s. 140).

Raunioista nousee entistä virtaviivaisempia ja ketterämpiä yrityksiä. $\mathrm{Ne}$, jotka selviytyvät, ovat hyvinkin saattaneet omaksua joitakin organisaa- 
tio-oppimisen taianomaisista salaisuuksista. Myös itse uskon, että 'oppiva organisaatio' edustaa suurta käsitteellistä edistysaskelta verrattuna vanhaan, individualistiseen andragogiseen malliin. Työn suunnittelun arkkitehtuuri sinänsä on se mittatikku, jota kehitystyössä on käytettävä. Työn tarkoituksenmukaisuuteen vaikuttavat keskeisesti sen vaatimien taitojen monipuolisuus, tehtävien tunnistettavuus ja niiden merkitys. Työntekijän autonomisuus vaikuttaa hänen vastuuntuntoonsa, ja palaute auttaa työntekijöitä tiedostamaan oman työnsä todelliset vaikutukset.

Nämä kriittiset psykologiset kokemukset ovat rakenteiden synnyttämiä, ja niiden tuottamat sisäiset tilat puolestaan vaikuttavat ihmisen työstään saamaan tyydytykseen ja hänen omistautumiseensa työyhteisölleen. Hyvä työ on suunnittelun tulos - se ei tapahdu itsestään. Uskoisin, että Harva ja Alanen väittäisivät, että todella merkitsevää oppimista voi tapahtua ainoastaan, jos työpaikka jokapäiväisten toimintojensa kautta tarjoaa kaikille työntekijöille tilaisuuksia kehittää kapasiteettiaan. Työtehtävien ja työn sisältöjen suunnittelu on se alue, jolla kehityshumanismi kohtaa suurimman haasteensa: välineellisyyden ja tehokkuuden logiikka piittaa hyvin vähän ihmisyksilön kasvusta ja kukoistuksesta.

'Kaikki työntekijät mukaan kehittämään omaa kapasiteettiaan.' Parhaimmillaan tämä on kaunis unelma, pahimmillaan vain julmaa pilaa. Mahdollisuus työhön, missä voi kehittyä, on yhä vain

Jos - Livingstonen mukaan -

ihmisten tietojen ja taitojen

alityöllistys kapitalistisilla

työmarkkinoilla on yhtä laajaa

kuin datasta on pääteltävissä,

elämänikäisen oppimisen kas-

vavaa tarvetta painottavat

suositukset eivät lainkaan ta-

voita kohdettaan. suhteellisen pienen, korkeasti koulutetun väestönosan etuoikeus. Suomessa ja muuallakin työn tutkijat ovat tyrmistyneet työmarkkinoiden kahtiajakautumisesta 'ydintyöntekijöihin' ja 'periferiatyöntekijöihin’ (Tuomisto 1998, 1999). ${ }^{2}$ Työttömyydestä on tullut oppivan yhteiskunnan pysyvä asukas. Monet läntisten liberaalien yhteiskuntien asukkaista eivät enää saavuta ensisijaista identiteettiään miellyttävän työn kautta. Risto Rinne (1998) väittää, että elämänikäisen oppimisen retoriikka jää vain musteeksi kiiltävällä UNESCO:n paperilla, mikäli liberaalit länsimaiset demokratiat eivät kykene luomaan ajatusta uudenlaisesta, pakotetun palkkatyön tuolla puolen olevasta yhteiskunnasta; palkkatyön, joka väistämättä näivettää yksilön sielun ja kehon ytimen. Kehityshumanistinen perspektiivi saattaa itse asiassa joutua sysätyksi merkityksettömyyteen, mikäli se ei kykene artikuloimaan kattavaa, luovasti uutta näkökulmaa siihen, mitä merkitsee panoksen antaminen sellaisen yhteiskunnan hyvinvointiin ja aktiviteetteihin, jossa palkkatyötä on tarjolla vähemmän ja jossa se ei ole ihmiselle yhtä välttämätöntä kuin nykyään. Ehkäpä keskeisen osan suomalaista työn tutkimusta ja organisaatioiden kehitystyötä tulisikin omistautua hillityn utopistisille pohdinnoille siitä, millä tavoin me käytämme aikaamme luovasti työn yhteiskunnan tuolla puolen.

$\mathrm{K}$ anadalainen työn ja koulutuksen tutkija, sosiologi David Livingstone (2000) väittää, että 'tietoyhteiskunta' elää ja voi hyvin. Aikuiset osallistuvat ennennäkemättömän korkeatasoiseen viralliseen koulutukseen, jatkokoulutukseen ja vapaamuotoiseen koulutukseen. Livingstone kuitenkin väittää, että 'tietoyhteiskunta' on vain illuusio. Hänen ydinajatuksensa on, että nykypäivän työpaikoilla ihmisten oppimiskapasiteetti on vakavasti alityöllistettynä. Tällä alityöllistyneisyydellä on useita ulottuvuuksia: kuilu lahjakkuuden käytössä, rakenteellinen työttömyys, ei-vapaaehtoinen osa-aikatyö, pätevyyskuilu, suorituskykykuilu ja subjektiivinen alityöllistyneisyys. Kuten 1930-luvulla, on tämäkin inhimillisen potentiaalin tuhlaus mittasuhteiltaan valtavaa ja riipaisevaa. Jos - Livingstonen mukaan - ihmisten tietojen ja taitojen alityöllistys kapitalistisilla työmarkkinoilla on yhtä laajaa kuin da- 
tasta on pääteltävissä, elämänikäisen oppimisen kasvavaa tarvetta painottavat suositukset eivät lainkaan tavoita kohdettaan. Pääpainotuksen tulisikin olla työn uudelleenorganisoimisessa siten, että useammat ihmiset kykenisivät legitiimeillä ja kestävillä tavoilla soveltamaan niitä tietoja ja taitoja, joita heillä jo on. Tasa-arvoisen ja humaanin oppimisen ajan yhteiskunnan suuntaviivat ovat siis selvästikin vielä hyvin kiistanalaisia.

\section{Kansalaisuus politiikan jälkeisenä} aikana

'Aktiivisen kansalaisuuden' ajatus on kehityshumanistisen perspektiivin keskeinen osatekijä. Itse asiassa kehityshumanistit arvostavat kansalaisyhteiskuntaa ja julkisia elämänalueita ensisijaisina alueina, joilla puheen ja toiminnan kyky voi avautua ja saada ilmaisunsa. Urpo Harva olisi epäilemättä kiinnittänyt huomiomme aristoteelisiin teemoihin. Aristotelelle 'hyvä elämä’ ei ollut jotakin, jonka voi omistaa; ihmisestä tuli hyvä, jos hän käytti näitä ainutlaatuisesti inhimillisiä kykyjä. Vapaana välttämättömyyksien maailman pakosta kansalaiset astuivat julkiselle areenalle, jolla saattoivat elää ja keskustella yhdessä. Tässä vapaassa julkisessa tilassa kansalaiset kykenivät sitten tunnistamaan yhteisyytensä sekä löytämään yksilöllisyytensä. Kansalaiset voivat kehittää ja soveltaa käytännön viisautta vain sellaisen harkinnan ja pohdinnan kautta, joka liittyy tiettyihin ongelmiin ja toimintatilanteisiin (Keane 1984, s. 117). On mahdollista, että vallitsevat poliittiset olosuhteet joko vääristävät kommunikaatioprosesseja tai jopa aktiivisesti tekevät mahdottomaksi kehittää käytännön poliittista viisautta ja taitoa.

$\mathrm{M}$ onet Euroopan ja Pohjois-Amerikan ajatelijat ovat syvästi huolissaan kansalaisosallistumisen ja poliittisen osallistumisen todellisesta tilasta maissaan. Jürgen Habermasin syystäkin kuuluisa analyysi 1960-luvun alkupuolella julkisen tilan rappeutumisesta oli merkki suurista vaikeuksista liberaaleissa länsimaisissa demokratioissa (ks. The Structural Transformation of the Public Sphere, 1962). Yksi niistä perimmäisistä kysymyksistä, joita kehityshumanistinen tradi- tio joutuu kohtaamaan, on juuri kysymys siitä, mitkä ovat ne mahdollistavat olosuhteet, joiden vallitessa verkostoituneessa maailmassamme voisi syntyä vahva demokratia. Tämä kysymys on tietenkin äärimmäisen kompleksi. Meidän on syytä olla valppaina ja ottaa järki käteen, sillä kyberdemokratian kauniiden unien näkijät uskovat verkkoteknologian jo sinällään taikovan meille uuden demokratian aikakauden! Tarvitaan siis maltillisempaakin näkemystä.

Z ygmunt Baumannin kaltainen harkitseva yheiskuntakriitikko yllättää meidät lausuessaan, että demokratia on kehittymässä yhä hampaattomammaksi ja kyvyttömämmäksi suojelemaan tai säätelemään kansalaisten elämän kannalta välttämättömiä olosuhteita ...: "Nykypäivän valtiot eivät kykene täyttämään toista elinvoimaisen tasavallan välttämätöntä ehtoa: kansalaisten mahdollisuutta neuvotella ja yhdessä päättää 'yhteisestä hyvästä' ja siten muovata yhteiskuntaa sellaiseksi, mitä olisivat valmiita kutsumaan omakseen ja jolle mieluusti vannoisivat horjumatonta uskollisuuttaan.” (1999, s. 169). Baumanin epätoivoinen näkemys ei kuitenkaan ota huomioon kansalaisaktiivisuuden, -keskustelun ja väittelyn sinnikästä läsnäoloa kansalaisyhteiskunnan erilaisissa vuorovaikutusympäristöissä. Teoksessaan Between Facts and Norms (1996) Habermas puolustaa ihmisten arkipäivän elämismaailmaa [lifeworld] ja kansalaisyhteiskuntaa neuvottelevan demokratian ensisijaisena oppimisympäristönä. Meidän ei tule sen paremmin antautua kyyniseen näkemykseen politiikasta kuin tyytyväisinä olettaa, että kehittyvän kansalaisuuden tulevaisuus on ilman muuta turvattu. Markkinat kyllä huolehtivat itsestään, mutta kansalaisyhteiskunta hajoaa, jos se jätetään oman onnensa nojaan. Ja kun kansalaisyhteiskunta joutuu alennustilaan ja ihmisten arkipäivän elämänpiiri rapautuu, kansalaisten osallistumisen henkiset ja moraaliset perustukset haihtuvat. Jos emme luota toisiimme, vaan ajattelemme aina oman etumme maksimointia, putoaa neuvottelu pois demokratiasta ja me asetumme toisiamme vastaan kilpailijoina ja muukalaisina.

Kä, että yhteiskunnat mobilisoisivat oppimis- 
resurssinsa elämänikäisesti ja elämän koko kirjon kattavasti hyvän yhteiskunnan palvelukseen edellyttää toteutuakseen runsasta sosiaalisen pääoman varastoa ja sellaisia yhteiskunnallisia rakenteita, joissa kansalaisyhteiskunnan elämällä on tilaa kukoistaa. Vaikuttavan laajaan aineistoon perustuvassa kirjassaan Bowling Alone: The collapse and revival of American Community (2000) Robert Putnam kiinnittää huomiomme demokraattisen itsehallinnon ja aktiivisesti osallistuvan väestön välillä vallitsevaan suhteeseen. Se, että demokraattinen itsehallinto edellyttää aktiivista, hyvin koulutettua väestöä, on itse asiassa ollut amerikkalainen aksiooma jo vuosisatojen ajan. Samoin suomalaiset ja kanadalaiset aikuiskasvatuksen tutkijat ovat vahvasti uskoneet väitteeseen siitä, että ainakin osittain julkisten instituutioiden terveys perustuu kansalaisten laajaan osallistumiseen yksityisten vapaaehtoisjärjestöjen toimintaan - näihin kansalaisosallistumisen verkostoihin, jotka ovat sosiaalisen pääoman ruumiillistuma" (2000, s. 336).

Putnam esittää, että terveet kansalaisjärjestöt muovaavat aktiivista kansalaisuutta neljällä eri tavalla.

- Ensiksikin yhdistykset ja kansalaisjärjestöt suovat yksilöille mahdollisuuden ilmaista hallinnolle omat kiinnostuksensa ja vaatimuksensa. Näiden verkostojen kautta virtaa poliittista oppimista ja niissä myös keskustellaan yhteisistä julkisen elämän asioista.

- Toiseksi yhdistykset ja järjestöt moninkertaistavat tai vahvistavat yksittäisten kansalaisten äänen.

- Kolmanneksi yhdistykset, järjestöt ja vähemmän viralliset kansalaisvaikuttamisen verkostot (sekä oppimiseen että toimintaan keskittyvät) voivat juurruttaa ihmisiin yhteistoimintatottumuksia ja yhteisöhenkisyyttä sekä tarjota kansalaisille mahdollisuuden hankkia niitä käytännön taitoja, joita tarvitaan julkiseen elämään osallistumisessa (emt.).

- Neljänneksi vapaaehtoisjärjestöt ovat potentiaalisia demokratiakouluja, joissa kansalaiset oppivat kokoustaitoja, oppivat puhumaan julkisesti ja ottamaan vastuuta yhteisistä asioista. Tässä yhteydessä on helppo nähdä, mikä tärkeä historiallinen merkitys suomalaisilla aikuiskasvatusins- tituutioilla - kansanopistoilla, sivistysjärjestöjen opintokerhoilla ja kansalais- ja työväenopistoilla - on ollut aktiivisen kansalaisuuden vaatimien tietojen, taitojen ja asenteiden vaalimiselle.

Putnam toteaa Yhdysvalloissa ja Kanadassa vapaaehtoisjärjestöjen ja kirkkojen tarjonneen usein parhaat mahdollisuudet kansalaistaitojen rakentamiseksi, ja jopa ammatti-ihmisille ne ovat kansalaistaitojen oppimispaikkoina tärkeydessä heti toisella sijalla työpaikan jälkeen. Yhdistykset voivat teroittaa ihmisten mieleen demokraattisia tapoja sekä toimia foorumeina, joilla voidaan harkiten neuvotella keskeisistä ongelmista (2000, s. 339). Putnamin mielestä vapaaehtoisjärjestöt eivät ainoastaan palvele neuvottelufoorumeina, vaan antavat tilaisuuden oppia kansalaishyveitä, kuten aktiivista osallistumista julkiseen elämään (emt.). Putnamin pohdinnoista nousee esiin tärkeä kriittinen teoreema: "Mitä enemmän ihmiset osallistuvat kansalaisosallistumisen verkostoihin (kerhojen kokouksista kirkon järjestämiin retkiin tai vaikkapa ystävysten vapaamuotoisiin tapaamisiin), sitä todennäköisemmin he osoittavat kiinnostusta toisten ihmisten ongelmiin myös yleisellä, abstraktilla tasolla...” (2000, s. 340). Tämä teoreema on aikuiskasvatuksen tutkijoiden kannalta merkittävä. Kriittinen oppimisteoria esittää, että dialogiset asenteet ovat keskeisiä syvien ja merkittävien oppimisprosessien kannalta. Mutta dialogisten asenteiden vaaliminen edellyttää kansalaisosallistumista tilanteissa, joissa vapaa ja pakottamaton keskustelu on mahdollista.

Putnamin itsensä mielestä kuitenkin merkittävät amerikkalaisessa yhteiskunnassa vallitsevat trendit uhkaavat hänen kehityshumanistista visiotaan. Alkuperäisessä, paljon kiitosta saaneessa artikkelissaan Bowling Alone Putnam havaitsi, että yhä suurempi osuus amerikkalaisista oli lakannut keilaamasta liigoissa ja siirtynyt keilaamaan itsekseen. Kun hän sitten laajensi artikkelinsa laajaksi empiiristen osallistumistutkimusten synteesiksi, löysi Putnam todisteita Amerikassa muhivasta suuren luokan kriisistä. "Vapaaehtoisjärjestöt sellaiset, joissa ihmiset vapaasti liittoutuvat keskenään jonkin asian hyväksi, kollektiivisesti ratkovat yhteisönsä ongelmia ja rakentavat sosiaali- 
sen luottamuksen verkostoja - ovat rappeutuneet." Osallistuminen yhteiskunnalliseen elämään on voimakkaasti vähenemässä. Putnamin ja hänen tukijoidensa mukaan amerikkalaiset eivät enää harjoita itsehallintoa ja demokratiaa (Mattson 1999). Amerikkalaiset ovat yksilöllistyneempiä, sosiaalisesti eristyneempiä ja vähemmän osallistuvia kuin koskaan ennen historiansa aikana. Kansalaisen rooli on supistunut ja kuluttajan rooli paisunut.

Netti-intoilijat kuitenkin kehottavat meitä olemaan huolehtimatta turhia, sillä kansalaisosallistumisen ja poliittisen osallistumisen kulttuurien rapautumisen aiheuttaman demokratiavajeen tilalle on muodostumassa mobiili informaatioyhteiskunta. Kuten Peter Kollock ja Marc Smith toteavatesseessään Communities in Cyberspace, "laajasti uskotaan ja toivotaan, että kommunikoinnin ja vuorovaikuttamisen helpottuminen verkossa johtaa demokraattisten instituutioiden kukoistukseen ja synnyttää uuden ja elinvoimaisen julkisen diskurssin foorumin" (sitaatti, Putnam 2000, s. 173).

$\mathrm{V}$ oimmeko siis puhua elektronisesti vahvistetusta voimakkaasta demokratiasta? Ensinäkemältä vaikuttaisi, että visio kyberavaruudesta suoran demokratian uutena eturintamana näyttää toiveittemme toteutumalta. Siinähän kansalaiset hakeutuvat kahdenkeskiseen vuorovaikutukseen toistensa kanssa hierarkisten hallitusten ja yritysten valvonnan ja sensuurin ulottumattomissa. Kuitenkin vain muutamia poikkeuksia lukuunottamatta internetistä löytyy hyvin vähän sellaista, mitä voitaisiin lainkaan kutsua 'kansalaistoiminnalliseksi' tai 'poliittiseksi'. Jos 'poliittista' tai 'kansalaistoiminnallista' käyttöä esiintyy, on se vain harvoin demokraattista käsitteen vahvassa, vuorovaikutteisessa ja osallistavassa mielessä.

Meidän mobiilin informaation aikanamme hyvän kansalaisen käsite edellyttää, että hallinnon demokraattinen järjestely antaa kansalaisille yhdenvertaiset mahdollisuudet ja kyvyt mielekkäästi osallistua niihin päätöksiin, jotka läheisesti vaikuttavat heidän yhteiseen elämäänsä yhteisöissä asuvina yksilöinä. Tämä kehityshumanis- tinen visio - unelma siitä, että tietoverkkovälitteinen viestintä synnyttää uusia ja parempia virtuaaliyhteisöjä, jotka kykenevät korvaamaan entiset, kasvokkain tapahtuviin kohtaamisiin perustuvat yhteisöt - joutuu kuitenkin kohtaamaan ainakin kolme vakavaa haastetta.

Ensimmäinen ongelma on 'digitaalikuilu'. Pääsy kyberavaruuteen ei ole koko väestölle yhtäläinen. Edessämme on eräänlaisen kyberapartheidin uhka, jossa siltoja rakentavien sosiaalisen pääoman muotojen osuus vähenee samalla, kun eliittiverkostot muuttuvat vähäosaisten kannalta yhä vaikeapääsyisemmiksi. Internet ei myöskään ole mobilisoinut aiemmin passiivisia ihmisryhmiä.

Toiseksi, tietokonevälitteinen viestintä välittää ei-kielellistä informaatiota paljon vähemmän kuin kasvokkain tapahtuva viestintä. Putnamin mielestä sanattomien sosiaalisten vihjeiden ja viestien vähäisyys tietokonevälitteisessä viestinnässä rajoittaa ihmistenvälisen yhteistyön ja luottamuksen syntyä - etenkin niissä tapauksissa, joissa vuorovaikutus on anonyymiä eikä liity johonkin laajempaan kontekstiin. Hän uskoo, että sosiaalinen pääoma saattaa osoittautua tehokkaan ja toimivan tietokonevälitteisen kommunikaation edellytykseksi eikä niinkään sen lopputulokseksi.

Kolmanneksi, meille yksilöinä ja pohjoisen pallonpuoliskon etuoikeutettuina asukkaina tekee Internet hyvin helpoksi rajoittaa kommunikointimme ihmisiin, jotka tarkkaan jakavat juuri meidän intressimme. Tämän lisäksi Internetin kehitystä ohjailevat kaupalliset kannustimet näyttävät väistämättä korostavan henkilökohtaista viihdettä ja kauppaa eivätkä niinkään yhteisöllistä osallistumista” (Putnam 2000, s. 179).

U umanistinen traditio antiikin kreikkalaisisvinvointia tärkeimpänä asiana (Lamont 1969, s. 30). Humanistinen traditio eri ilmenemismuodoissaan on aina asettunut vastustamaan niitä voimia, jotka ovat pyrkineet estämään ihmisyksilön monipuolisten kykyjen puhkeamista kukoistukseen. Uskon, että suomalaisen aikuiskasvatus- 
tutkimuksen perinne todistaa, että ihmisen yksilönkehitys tarvitsee rakenteita, jotka sallivat ihmisten ilmaista monipuolista potentiaaliaan. Ilman hyvää työtä ja aktiivista kansalaisuutta niihin liittyvine tunteineen siitä, että elämä on elämisen arvoista, muuttuu elämä ankeaksi. Ja tämän ankeuden patologiset seuraamukset läpäisevät koko elämänpiirimme. Oppivassa taloudessa todellisuudessa vallitsevat rakenteet saattavat ehkäistä aikuisiässä tapahtuvan jatkuvan kehittymisen. Meidän on kyettävä tekemään ja luomaan toisiamme hyödyttäviä asioita ja palveluja. Julkisen elämän alue on myös edelleen se perusalue, jolla aikuiset ihmiset voivat toteuttaa itseään ja löytää kyvyilleen ilmaisun autenttisina puhujina ja päätöksentekijöinä.

Jos oppimisen aikakautemme asettaa esteitä merkityksellisen työn ja kansalaisuuden tielle, on seurauksena tosiasiassa valtavan padon syntyminen elämänpiiriimme. Pato kohoaa kohoamistaan, ja lopulta sen muurit murtuvat (Welton 1995, ss. 148-149). Oppivan yhteiskunnan juhlallisesti julistettu esiinmarssi 21. vuosisadalla ei itsessään ole mikään tae siitä, että tuo yhteiskunta olisi myös hyvä ja oikeudenmukainen.

\section{Viite}

Tekstissä olevat käsitteet ydintyöntekijä ja periferiatyöntekijä ovat Jukka Tuomiston. Kääntäjä käytti termejä avainosaajat ja toisarvoiset työntekijät, mitkä termit myös tavoittavat hyvin Tuomiston ajatuksen.

\section{Lähteet}

ALBROW, M. (2000) Travelling beyond local cultures. In F. Lechner and J. Boli, (Eds.) The Globalization Reader. Oxford: Blackwell Publishers, 118-125.

BARNEY, Darin (2000) Prometheus Wired: The hope for democracy in the age of network technology. Vancouver: UBC Press.

BAUMAN, Z. (1999) In Search of Politics. Stanford: Stanford University Press.

BRAVERMAN, Harry (1974) Labour and Monopoly Capital: The degradation of work in the 20th century. New York: Monthly Review Press

DEWS, P. (ed.) (1992) Autonomy and Solidarity: Interviews with Jürgen Habermas. London: Verso.

ENGELS, Friedrich (1969, orig. 1844) The Condition of the Working Class in England, St. Albans, UK: Panther Books

HABERMAS, Jürgen (1962) The Structural Transformation of the Public Sphere. Cambridge: MIT Press
KAGARLITSKY, B. (2000) The Return of Radicalism: Reshaping the left institutions. London: Pluto Press.

KEANE, J. (1984) Public Life and Late Capitalism. Towards a socialist theory of democracy. Cambridge: Cambridge University Press.

LAMONT, C. (1969) The Philosophy of Humanism. NY: Frederick Ungar.

MATTSON, K. (1999) State of the Union. In These Times, February 21, 22-23.

LIVINGSTONE, D.W. (1999) Lifelong learning and underemployment in the knowledge society. In: Comparative Education, vol. 35 (2). 163-186.

MAYOR, F. (1997) Adult Education: The Hamburg Declaration, The agenda for the future. Fifth International Conference on Adult Education, 1418 July.

PLUMB, D. (1999) Adult education in a world "on speed". In: Studies in Continuing Education, vol. 21 (2).

PUTNAM, R. (2000) Bowling Alone: The collapse and revival of American community. NY: Simon and Schuster.

RINNE, R. (1998) From labour to learn: the limits of labour society and the possibility of learning society. In: International Journal of Lifelong Education, vol. 17, March-April,. 108-120.

RULE, J. (2000) The information society, the new economy, and the hype. In Dissent, Fall.

SENNETT, Richard (1998) The Corrosion of Character New York: W.W. Norton and Co.

TUOMISTO, J. (1998) Demands and Possibilities for lifelong learning in a market-oriented economy: a Finnish perspective on public policy and reality." In: J. Holford, P. Jarvis, C. Griffin (Eds.) International Perspectives on Lifelong Learning. London: Kogan Page, 155-167.

TUOMISTO, J. (1999) Social structure and lifelong learning: critical analysis of learning opportunities in working life. In: S. Tosse (Ed.) Challenges and development: Adult Education Research in Nordic Countries. Trondheim: Tapir Academic Press.

WELTON, M. (1995) In defense of the lifeworld: A Habermasian approach to adult learning. In: M. Welton (ed.) In Defense of the Lifeworld. Albany: SUNY Press. 127-156.

ZUBOFF, S. (1988) In the Age of the Smart Machine. NY: Basic Books.

Julkaistun tekstin pohjana on professori Michael Weltonin Aikuiskasvatus-lehden 20-vuotisjuhlaseminaarissa 13.12.2000 pitämä esitelmä. Michael Welton on väitellyt British Columbian yliopistossa aiheesta Education and Policy Studies. Viime vuonna häneltä ilmestyi elämänkerta "Little Mosie from the Margaree". Yhteystiedot: Prof. Michael Welton,

Mount Saint Vincent University, Department of Education, Graduate Adult Education Programme, Halifax,

Nova Scotia B3M 2J6, Canada

Tel 1902457 6147, Fax 19024574911

Email michael.welton@msvu.ca,www.msvu.ca

Käännös: KIMMO ABSETZ

Käännöksen tarkistus: JUKKA TUOMISTO

Kuvat:KALEVIKESKI-KORHONEN 